\title{
Microshear bond strength of universal adhesives to enamel and dentin: an eighteen-month in vitro study
}

Resistência de união ao microcisalhamento de adesivos universais ao esmalte e dentina: estudo in vitro de dezoito meses

Rubens Nazareno GARCIA ${ }^{1,2}$ (D), Vitaliano Gomes de ARAÚJO NETO ${ }^{3}$ (D), Camila Ribeiro SILVA ${ }^{3}$ (D), Luiz Carlos Machado MIGUEL ${ }^{4}$ (D), Marcelo GIANNINI ${ }^{3}$ (D)

1 - Universidade do Vale do Itajaí, Curso de Odontologia, Área Materiais Dentários e Clínica Integrada, Itajaí, SC, Brasil.

2 - Universidade da Região de Joinville, Curso de Odontologia, Área Materiais Dentários e Clínica Integrada, Joinville, SC, Brasil.

3 - Universidade Estadual de Campinas, Faculdade de Odontologia de Piracicaba, Departamento de Odontologia Restauradora,

Piracicaba, SP, Brasil.

4 - Universidade da Região de Joinville, Curso de Odontologia, Área Dentística e Clínica Integrada, Joinville, SC, Brasil.

\begin{abstract}
Objective: The aim of this study was to evaluate the microshear bond strength of Universal adhesives to enamel and dentin after one week and eighteen months of water storage. Material and Methods: Fragments from the buccal surfaces of 80 bovine teeth were prepared $(12 \times 5 \times 1.0 \mathrm{~mm})$ and ground to obtain flat surfaces of enamel and dentin. Samples were randomly assigned to 8 experimental groups $(n=10)$, according to four adhesive systems (Adper Single Bond Plus/control - not a Universal adhesive/ASB; Ambar Universal/AUN; Prime\&Bond Active/PBA and Scotchbond Universal/SBU) and two water-storage times (one week and eighteen months after sample preparations). Adhesives were applied according to the manufacturers' instructions and molds were positioned over bonded surfaces. A flowable composite was poured into the molds to fill up their internal diameter and obtain resin cylinder $(1.0 \mathrm{~mm}$ height/0.7mm internal diameter) after light-curing. Bond strength was determined using a testing machine $(0.5 \mathrm{~mm} / \mathrm{min}) \mathrm{and}$ data were statistically analyzed by two-way analysis of variance (ANOVA) and the post-hoc Tukey's test (alpha $=0.05$ ). Failure patterns were analyzed for all resin cylinder tested. Results: For enamel, differences among adhesives were observed only at 18 months, in which SBU produced lower bond strength values $(15.9 \pm 3.0 \mathrm{MPa})$ than the others universal adhesives (AUN: 19.3 \pm 4.8 and PBA: $21.4 \pm 2.1 \mathrm{MPa})(\mathrm{p}<0.05)$. For dentin, there were differences among adhesives only at 7 days, with PBA showing the highest bond strength (37.4 $\pm 4.9 \mathrm{MPa})$ and ASB the lowest one $(19.4 \pm 3.9 \mathrm{MPa})(\mathrm{p}<0.05)$. Enamel and dentin bond strength of all adhesives decreased significantly after $18 \mathrm{months}$ and reduction percentage varied from 36.9 to 52.4 for enamel and from 35.1 to 62.8 for dentin. Adhesive and mixed failures showed high incidences. Conclusion: Results suggested that adhesives presented differences among them depending on type of hard dental tissue and evaluation time. Enamel and dentin bond strengths of control and all universal adhesives tested were not stable, decreasing at eighteen months.
\end{abstract}

\section{KEYWORDS}

Hard Dental tissues; Bonding agents; Adhesion; Water storage.

\section{RESUMO}

Objetivo: O objetivo deste estudo foi avaliar a resistência de união ao microcisalhamento de adesivos universais ao esmalte e dentina após uma semana e dezoito meses de armazenamento em água. Material e Métodos: Fragmentos da superfície vestibular de 80 dentes bovinos foram preparados $(12 \times 5 \times 1,0$ mm) até o obtenção de superfícies planas de esmalte e dentina. As amostras foram distribuídas aleatoriamente em 8 grupos experimentais $(\mathrm{n}=10)$, de acordo com quatro sistemas adesivos (Adper Single Bond Plus / controle - não universal; Ambar Universal; Prime \& Bond Active e Scotchbond Universal) e dois tempos de armazenamento em água (uma semana e dezoito meses após o preparo das amostras). Os adesivos foram aplicados de acordo com as instruções dos fabricantes e as matrizes foram posicionadas sobre as superfícies aderidas. Um compósito fluido foi aplicado 
nas matrizes para preencher seu diâmetro interno e obter o cilindro do compósito por fotopolimeração ( 1,0 mm de altura / 0,7 mm de diâmetro interno). A resistência de união foi determinada em uma máquina universal de ensaios $(0,5 \mathrm{~mm} / \mathrm{min})$. Os dados foram analisados estatisticamente pela análise de variância dois fatores (ANOVA) e teste de Tukey (alfa 0,05). Resultados: Para o esmalte, foram obtidas diferenças apenas aos 18 meses, em que Scotchbond Universal produziu menor média de resistência de união do que os demais adesivos universais. Para dentina, houve diferenças entre os adesivos apenas aos 7 dias, com o Prime \& Bond Active apresentando a maior resistência de união e o Adper Single Bond Plus a menor. Os resultados sugeriram que os adesivos apresentaram diferenças entre si dependendo do substrato e do tempo de avaliação. Conclusão: As resistências de união em esmalte e dentina do controle e de todos os adesivos universais testados não foram estáveis, diminuindo aos dezoito meses.

\section{PALAVRAS-CHAVE:}

Adesivos dentinários; Dentina; Esmalte dentário; Armazenamento de água.

\section{INTRODUCTION}

In 1955, Buonocore proposed the acid enamel conditioning technique, which boosted adhesive dentistry. The traditional bonding mechanism to hard dental tissues (etch-and-rinse technique) is based on the superficial demineralization of the enamel and dentin followed by infiltration of the methacrylate-based adhesive monomers that results in micromechanical retention [1]. In addition, functional monomers have been incorporated to adhesive systems that are capable of forming a chemical bond mainly with calcium from dental structures without the need to etch hard dental tissues with phosphoric acid gel. These adhesives are known as self-etching or Universal, characterized by simplifying the application technique and saving clinical time. The universal adhesive systems can be used in etch-and-rinse or self-etching mode $[2,3]$.

In enamel, the phosphoric acid conditioning creates an etching pattern that increases the surface roughness, creating porosities where the adhesive monomers penetrate and to form the mechanical interlocking [4,5]. Enamel bonding is considered safe and reliable compared to dentin, as enamel is a hard dental tissue basically composed of inorganic matter in a prismatic structure. Universal adhesive solutions have a less acidity composition compared to $37 \%$ phosphoric acid gel with the possibility to work as a selfetching adhesive. Acidic functional monomers have reduced demineralization potential, but are able to chemically react with mineral phase of the enamel $[6,7]$.

The bonding mechanism of self-etching adhesives to dentin is more complex. These adhesives contain functional monomers derived from sulfonic acid, phosphate, phosphonate and carboxyl groups with different $\mathrm{pH}$ and they have the function of conditioning, infiltrating into dentin, reacting chemically with calcium from hydroxyapatite and leading to the adhesion with dentin $[7,8]$. Universal adhesives with low $\mathrm{pH}$ can cause greater demineralization of the dentin structure [9]. However, it is recommended for adhesion to dentin, the use of mild acidity monomers to provide better bonding stability [10]. The more superficial adhesion to dentin substrate without aggressive etching is an important step to reduce the risk of postoperative sensitivity and the exposure of collagen fibers that can undergo early degradation, impacting the stability of the bonding over time [11-13].

While the acid etching benefits the resin-enamel bonding and smear layer removal, the dentin collagen exposure by phosphoric acid etching or with very acidic self-etching adhesives results in bonding interface highly vulnerable to hydrolytic and enzymatic degradation processes, with in decreased bond strength in the short and long-term [12]. Also, the entire dentin demineralized superficial region with exposed collagen fibrils might be incompletely infiltrated by adhesive monomers. The lack of monomer penetration is mainly observed below the hybrid layer formation, where the mineral loss and low $\mathrm{pH}$ can activate collagenolytic enzymes. Theoretically, for self-etching adhesives this is minimized, because the conditioning effects produced by acidic functional monomers are less aggressiveness compared to that of phosphoric and the adhesive monomers are able to almost complete the infiltration to entire demineralized regions $[14,15]$. 
Because there are differences among compositions regarding universal adhesive system that could compromise immediate and long-term durability of bonding to dentin [16-18], this study aimed to compare the microshear bond strength of Universal adhesives to one etch-and-rinse, two-steps conventional adhesive to enamel and dentin, after one week and eighteen months of water storage. Additionally, fracture modes of tested samples were analyzed in scanning electron microscopy. The null hypothesis tested was that enamel and dentin bond strengths would not reduced after eighteen-months water-storage.

\section{MATERIAL AND METHODS}

\section{Study materials}

Four adhesives (Table I) were used in this study: a two-steps, etch-and-rinse adhesive (Adper Single Bond Plus, 3M Oral Care, St. Paul, MN, USA) was used as control, and three Universal adhesives: 1- Ambar Universal (FGM, Joinville, SC, Brazil); 2- Prime\&Bond Active (Dentsply Sirona, Konstanz, Germany) and 3Scotchbond Universal (3M Oral Care, St. Paul, MN, USA). The adhesives and the flowable composite (Filtek Bulk Fill Flow, 3M Oral Care, St. Paul, MN, USA) were used according to the manufacturer's instructions.

\section{Sample preparation}

Eighty bovine incisors were stored at $6^{\circ} \mathrm{C}$ for three months after extraction and used in this study. The roots were removed using a diamond disk (Isomet 1000, Buehler Ltd., Lake Bluff, IL, USA). Buccal and lingual enamel surfaces were flattened using 200-grit SiC paper to obtain parallel surfaces between them and forty teeth were used for testing the bond strength to enamel and other 40 teeth for dentin bonding testing. Enamel and dentin samples were prepared from buccal surfaces with dimensions of $12 \mathrm{~mm}$ in length and $5 \mathrm{~mm}$ in width. Thickness varied according to the type of dental hard tissue: $3 \mathrm{~mm}$ for enamel and $2.5 \mathrm{~mm}$ for dentin samples. Dentin surfaces were obtained by the removal of the buccal enamel.

The enamel and dentin surfaces of the samples were wet-abraded with 600-grit SiC paper (Carborundum, Guarulhos, SP, Brazil) to simulate the dental cutting using carbide bur and to form smear layer at dentin surfaces. Forty enamel and forty dentin samples were randomly divided into 4 experimental groups, according to the four tested adhesive systems $(n=10)$.

\section{Shear bond strength testing}

The methodology developed by Shimada et al. [19] was used to prepare

Table I - Materials, manufacturers, compositions and instructions

\begin{tabular}{|c|c|c|}
\hline Adhesive (manufacturer) & Composition (lot number and pH) & Application Technique \\
\hline \multirow{4}{*}{$\begin{array}{l}\text { Adper Single Bond Plus ( } 3 M \\
\text { Oral Care, St. Paul, MN, USA) }\end{array}$} & \multirow{4}{*}{$\begin{array}{l}\text { Bis-GMA; HEMA; copolymer of acrylic and itaconic } \\
\text { acids; GDMA; UDMA; silane treated silica; ethyl alcohol, } \\
\text { diphenyliodonium hexafluorophosphate, water; (lot N750327; } \\
\text { pH = 4.7). }\end{array}$} & - 37\% phosphoric acid for $30 \mathrm{~s}$ \\
\hline & & - rinse for $10 \mathrm{~s}$ \\
\hline & & - air dry for $10 \mathrm{~s}$ \\
\hline & & - light cure for $10 \mathrm{~s}$ \\
\hline \multirow{3}{*}{$\begin{array}{l}\text { Ambar Universal (FGM } \\
\text { Produtos Odontológicos, } \\
\text { Joinville, SC, Brazil) }\end{array}$} & \multirow{3}{*}{$\begin{array}{l}\text { Bis-GMA; 10- MDP, hydrophilic methacrylated monomers, } \\
\text { HEMA; UDMA; ethyl-4 dimethyaminobenzoate, ethyl alcohol; } \\
\text { silanized silicon dioxide, camphorquinone, water (lot\# } 270218 \text {, } \\
\text { pH = 2.6-3.0). }\end{array}$} & - apply and rub for $20 \mathrm{~s}$ (repeat) \\
\hline & & - air dry for $10 \mathrm{~s}$ \\
\hline & & - light cure $10 \mathrm{~s}$ \\
\hline \multirow{3}{*}{$\begin{array}{l}\text { Prime\&Bond Active (Dentsply } \\
\text { Sirona, Konstanz, Germany) }\end{array}$} & \multirow{3}{*}{$\begin{array}{l}\text { Bisacrylamide } 1 \text { and 2; 10-MDP; PENTA; 4-(dimethylamino) } \\
\text { benzonitrile; isopropyl alcohol; water, initiator and stabilizer. } \\
\text { (lot\# 1609000096, pH = 2.5). }\end{array}$} & - apply and rub for $20 \mathrm{~s}$ \\
\hline & & - air dry for 5 s \\
\hline & & - light cure $10 \mathrm{~s}$ \\
\hline \multirow{3}{*}{$\begin{array}{l}\text { Scotchbond Universal ( } 3 M \\
\text { Oral Care, St. Paul, MN, USA) }\end{array}$} & \multirow{3}{*}{$\begin{array}{l}\text { 10-MDP, phosphate monomer, dimethacrylate resins, HEMA, } \\
\text { methacrylate-modified polyalkenoic acid copolymer, filler, } \\
\text { ethanol, water, initiators, silane (lot\# N750327, pH = 2.7). }\end{array}$} & - apply and rub for $20 \mathrm{~s}$ \\
\hline & & - air dry for $5 s$ \\
\hline & & -light cure for $10 \mathrm{~s}$ \\
\hline \multirow{2}{*}{$\begin{array}{l}\text { Filtek Bulk Fill Flow (3M Oral } \\
\text { Care, St. Paul, MN, USA) }\end{array}$} & \multirow{2}{*}{$\begin{array}{l}\text { Bis-GMA; UDMA; Bis-EMA; procrylate resins; ytterbium fluoride; } \\
\text { silane treated ceramic initiator; stabilizer; metal oxides (lot\# } \\
\text { N459958). }\end{array}$} & - apply \\
\hline & & - light cure for $20 \mathrm{~s}$ \\
\hline \multicolumn{3}{|c|}{$\begin{array}{l}\text { Abbreviations: GDMA- Glycerol 1,3-dimethacrylate; Bis-GMA- Bisphenol A glycidyldimethacrylate; UDMA- dimethacrylate urethane; } \\
\text { Bis-EMA- Bisphenol A ethoxyladodimethacrylate; HEMA- hydroxyethylmethacrylate; PENTA- Dipentaerythritol pentaacrylate phosphate; } \\
\text { 10-MDP-10-methacryloyloxydecyl dihydrogen phosphate. }\end{array}$} \\
\hline
\end{tabular}


the samples for the microshear test. After adhesive application, four cylindrical translucent molds (Tygon tubing, TYG-030, Saint-Gobain Performance Plastic, Maime Lakes, FL, USA) were positioned onto the bonded enamel or dentin surface of each sample, filled with the flowable resin and removed after composite light-activation to expose four resin cylinders ( $0.7 \mathrm{~mm}$ diameter by $1.0 \mathrm{~mm}$ high/ $0.38 \mathrm{~mm}^{2}$ ) bonded to each enamel and dentin sample. Each resin cylinders was checked under an optical microscope (30X) to verify interfacial defects and bubble inclusion. Eighty enamel and dentin samples containing the four resin cylinder were stored in distilled water at $37^{\circ} \mathrm{C}$ and two resin cylinders of each sample were tested after storage for one week, while the remaining two resin cylinders from the same sample after eighteen months. The water was changed monthly.

To perform the bond strength test, the lingual surface of enamel and dentin samples was attached to the testing device with cyanoacrylate glue and each resin cylinder was tested in a universal testing machine (Ez-test, Shimadzu Corp., Kyoto, Japan). A shear load was applied to the base of the resin cylinder with a thin wire $(0.2 \mathrm{~mm}$ diameter $)$ at a crosshead speed of $0.5 \mathrm{~mm} / \mathrm{min}$ until failure. The bond strength mean for each enamel and dentin sample was calculated from the bond strength average from the two resin cylinders bonded to enamel or dentin, according to the type of adhesives and evaluation times $(n=10)$. The shear bond strengths were calculated and expressed in MPa. The enamel and dentin bond strength results were analyzed separately. Data were analyzed statistically using a two-way analysis of variance (factors: adhesive and evaluation time) and the post-hoc Tukey test (alpha $=0.05$ ).

\section{Failure mode analysis}

Tested enamel and dentin samples were dehydrated in ascending ethanol concentrations (25\%, 50\%, 75\%, 95\% and 100\%), immersed in hexamethydisilazane for 10 minutes, mounted on aluminum stubs after drying, sputter coated with gold/palladium (SCD 050, Baltec, Vaduz, Liechtenstein), and then observed under high vacuum of a scanning electron microscope (SEM VP-435, Leo, Cambridge, United Kingdom).

The failures were classified as: Type 1: adhesive failure between bonding agent and enamel or dentin; and between bonding agent and low-viscosity resin; Type 2: cohesive failure within low-viscosity resin; Type 3 , cohesive failure within enamel or dentin; Type 4: cohesive failure within adhesive layer, and Type 5: mixed failure. Photomicrographs of representative areas of the fractured surfaces were taken at $100 \mathrm{X}$ magnification to analyze the fracture pattern of the tested samples.

\section{RESULTS}

\section{Enamel shear bond strength}

The enamel shear bond strengths of adhesives after one week and eighteen months are shown in Table II. Statistical results indicated that adhesive and evaluation time factors significantly influenced the bond strength results, as well as the interaction between factors was statistically significant $(\mathrm{p}<0.05)$. Enamel bond strength differences among adhesives were observed only after eighteen months, in which Scotchbond Universal produced lower bond strength values $(15.9 \pm 3.0 \mathrm{MPa})$ than those yielded for other universal adhesives (Ambar Universal: $19.3 \pm 4.8$ and Prime\&Bond Active: $21.4 \pm 2.1 \mathrm{MPa})$. However, the bond strength of Scotchbond Universal did not differ from Adper

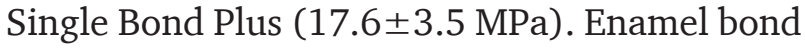
strength for all adhesives significantly decreased after eighteen months water storage and the percentage of reduction ranged from $36.9 \%$ (Prime\&Bond Active) to 52.4\% (Scotchbond Universal).

\section{Dentin shear bond strength}

The dentin shear bond strengths of adhesives after one week and eighteen months are shown in Table III. Statistical results indicated that adhesive and evaluation time factors significantly influenced the bond strength results, as well as the interaction between factors was statistically significant $(\mathrm{p}<0.05)$. After one week, Prime\&Bond Active presented the highest dentin bond strength (37.4 $\pm 4.9 \mathrm{MPa})$, the Adper Single Bond Plus the lowest one $(19.4 \pm 3.9 \mathrm{MPa})$, while the other two Universal adhesives the intermediate means (Scotchbond Universal: 25.9 $\pm 4.3 \mathrm{MPa}$ and Ambar Universal: 27.1 $\pm 6.6 \mathrm{MPa}$ ). After eighteen months, adhesives did not differ among them. Dentin bond strength for all adhesives also significantly reduced after eighteen months 
water storage, compared to one-week storage. The percentage of reduction ranged from $35.1 \%$ (Adper Single Bond Plus) to 62.8\% (Prime\&Bond Active).

\section{Failure mode analysis}

The types of failure and their respective prevalence (\%) are shown in the Table IV to VII and representative images of adhesive and mixed failures are presented in the Figures 1 and 2, respectively. For enamel and dentin, type 1 (adhesive failure) presented high incidence (Figure 1), regardless the type of adhesive and evaluation time, followed by type 5 failures (mixed) (Figure 2). Low percentage of type 2 failure (cohesive within composite) was obtained for both hard dental tissues and evaluation times (Table IV). Changes in the type

Table II - Shear bond strength to enamel (MPa \pm SD) and percentage (\%) of reduction of bond strength after eighteen months of aging

\begin{tabular}{|cccc} 
Adhesive & & Bond strength to enamel & \\
\cline { 3 - 4 } systems & 7 days & 18 months & Reduction (\%) \\
\hline Adper Single Bond Plus & $36.7 \pm 3.1$ a A & $17.6 \pm 3.5$ ab B & 52.0 \\
Ambar Universal & $34.0 \pm 7.6$ a A & $19.3 \pm 4.8$ a B & 43.2 \\
\hline Prime\&Bond Active & $33.9 \pm 6.1$ a A & $21.4 \pm 2.1$ a B & 36.9 \\
\hline Scotchbond Universal & $33.4 \pm 4.7$ a A & $15.9 \pm 3.0$ b B & 52.4 \\
\hline
\end{tabular}

Small case letters compare adhesives within the same evaluation time ( $p>0.05)$. Capital letters compare evaluation times for the same adhesive $(p>0.05)$

Table III - Shear bond strength to dentin (MPa \pm SD) and percentage (\%) of reduction of bond strength after eighteen months of aging

\begin{tabular}{|c|c|c|c|}
\hline Adhesive & \multicolumn{3}{|c|}{ Bond strength to dentin } \\
\hline systems & 7 days & 18 months & Reduction (\%) \\
\hline Adper Single Bond Plus & $19.4 \pm 3.9$ c A & $12.6 \pm 2.9$ a B & 35.1 \\
\hline Ambar Universal & $27.1 \pm 6.6 \mathrm{~b} \mathrm{~A}$ & $17.1 \pm 4.5$ a B & 36.9 \\
\hline Prime\&Bond Active & $37.4 \pm 4.9$ a $A$ & $13.9 \pm 5.5$ a B & 62.8 \\
\hline Scotchbond Universal & $25.9 \pm 4.3 \mathrm{~b} \mathrm{~A}$ & $16.4 \pm 2.9$ a B & 36.7 \\
\hline
\end{tabular}

Small case letters compare adhesives within the same evaluation time ( $p>0.05)$. Capital letters compare evaluation times for the same adhesive $(p>0.05)$.

Table IV - Failure modes (\%) of tested enamel samples (7 days)

\begin{tabular}{ccccc} 
Group & Type 1 & Type & Type 3 & Type 4 \\
\hline Adper Single Bond Plus & 47 & 0 & 7 & 23 \\
Ambar Universal & 70 & 0 & 13 & 7 \\
Prime\&Bond Active & 53 & 7 & 3 & 10 \\
\hline Scotchbond Universal & 53 & 3 & 7 & 3
\end{tabular}

Type 1: adhesive failure between bonding agent and enamel, and between bonding agent and low-viscosity resin; Type 2: cohesive failure within low-viscosity resin; Type 3: cohesive failure within enamel; Type 4: cohesive failure within adhesive layer; and Type 5: mixed failure.

Table V - Failure modes (\%) of tested dentin samples (7 days)

\begin{tabular}{cccccc} 
Group & Type 1 & Type 2 & Type & Type 4 & 17 \\
\hline Adper Single Bond Plus & 50 & 3 & 13 & 17 \\
Ambar Universal & 87 & 0 & 0 & 0 \\
Prime\&Bond Active & 90 & 0 & 0 & 0 \\
Scotchbond Universal & 67 & 7 & 0 & 7
\end{tabular}

Type 1: adhesive failure between bonding agent and dentin, and between bonding agent and low-viscosity resin; Type 2: cohesive failure within low-viscosity resin; Type 3: cohesive failure within dentin; Type 4: cohesive failure within adhesive layer; and Type 5: mixed failure. 
Table VI - Failure modes (\%) of tested enamel samples (18 months)

\begin{tabular}{|cccccc|}
\hline Group & Type 1 & Type 2 & Type 3 & Type 4 & Type 5 \\
\hline Adper Single Bond Plus & 62 & 0 & 7 & 11 & 20 \\
\hline Ambar Universal & 72 & 0 & 0 & 0 & 28 \\
\hline Prime\&Bond Active & 85 & 0 & 0 & 0 & 15 \\
\hline Scotchbond Universal & 76 & 8 & 0 & 0 & 16 \\
\hline
\end{tabular}

Type 1: adhesive failure between bonding agent and enamel, and between bonding agent and low-viscosity resin; Type 2: cohesive failure within low-viscosity resin; Type 3: cohesive failure within enamel; Type 4: cohesive failure within adhesive layer; and Type 5: mixed failure.

Table VII - Failure modes (\%) of tested dentin samples (18 months)

\begin{tabular}{|cccccc|} 
Group & Type 1 & Type 2 & Type 3 & Type 4 & Type 5 \\
\hline Adper Single Bond Plus & 56 & 0 & 7 & 17 & 20 \\
\hline Ambar Universal & 66 & 0 & 0 & 0 & 16 \\
\hline Prime\&Bond Active & 66 & 8 & 0 & 13 & 26 \\
\hline Scotchbond Universal & 57 & 0 & 30
\end{tabular}

Type 1: adhesive failure between bonding agent and dentin, and between bonding agent and low-viscosity resin; Type 2: cohesive failure within low-viscosity resin; Type 3: cohesive failure within dentin; Type 4: cohesive failure within adhesive layer; and Type 5: mixed failure.

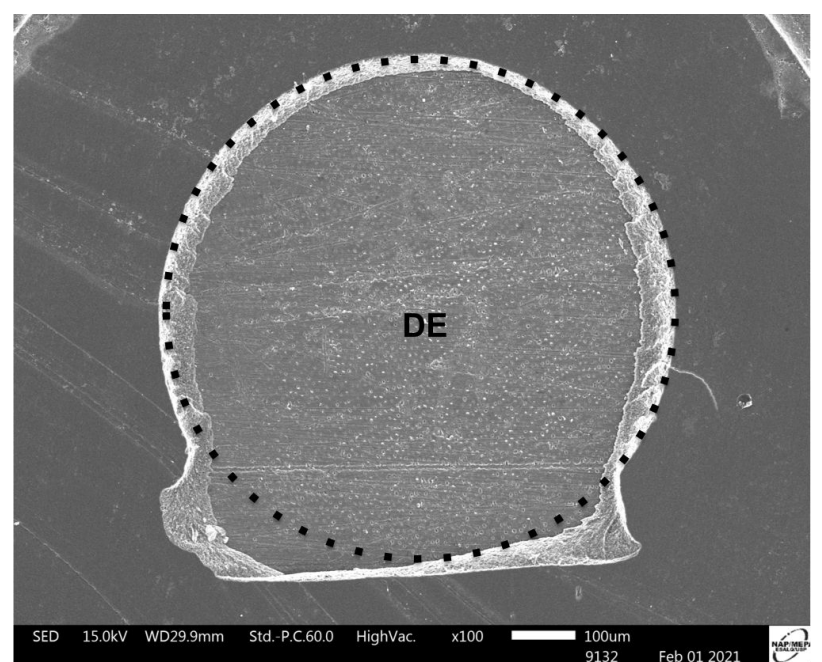

Figure 1 - Representative SEM image of adhesive failure, exposing the dentin surface (DE). This failure occurred in a sample tested at 18 months of Adper Single Bond Plus. Original magnification 100x.

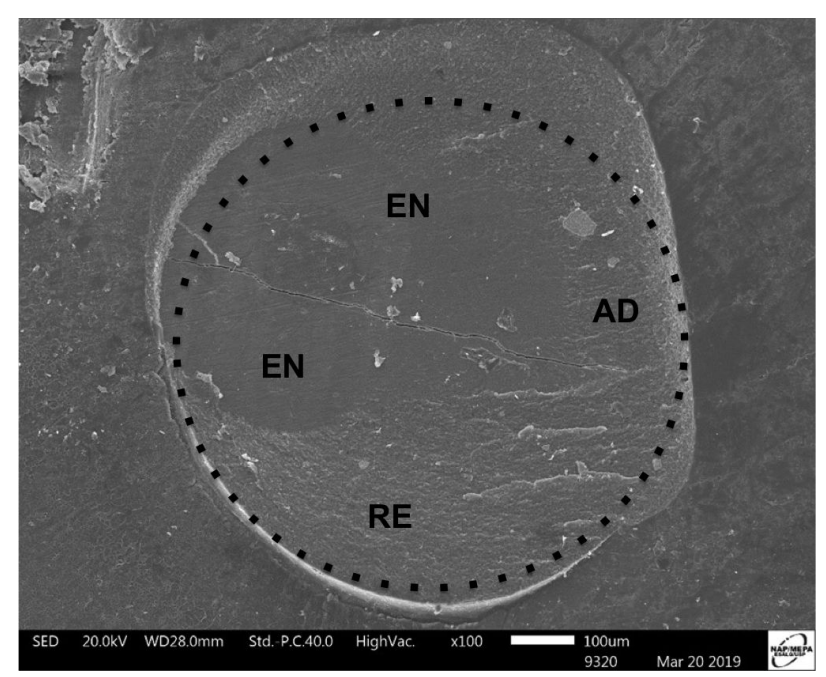

Figure 2 - Representative SEM image of mixed failure, involving lowviscosity resin (RE), adhesive layer (AD) and the exposure of enamel surface (EN). This failure occurred in a sample tested at seven days of the Ambar Universal adhesive. Original magnification 100x. of failure with the increase in the storage time of the samples were not observed.

\section{DISCUSSION}

The null hypothesis tested that enamel and dentin bond strengths would not reduce after long-term water storage was rejected, because both bond strength decreased significantly after eighteen months. Thus, these results indicated unstable adhesion in both dental hard tissues until eighteen months, regardless the type of adhesives. Also, Universal and control adhesives presented the same behavior in this study.

Universal adhesives used the self-etch mode to bond to enamel, while Adper Single Bond Plus was applied to etched enamel with phosphoric acid, which increases the enamel's surface energy with the mineral dissolution and creates microporosities at the enamel interprismatic area [20]. However, no statistical difference was observed between them at 7 days of storage. The reason that bond strength means were not different among groups was related to the low $\mathrm{pH}$ that the universal adhesive systems present in their composition (Table I). This low $\mathrm{pH}$ seemed to be enough to created the porosities for the universal adhesive system penetrate throughout the enamel, specially because they were applied in an active mode for 20 seconds $[13,17,18]$.

At eighteen months, enamel bond strength of all adhesives decreased compared with seven days evaluation and Scotchbond Universal showed lower bond strength than those obtained 
with other two Universal adhesives, but it did not differ from the control. Perhaps, the water/ solvent content in each adhesive system may explain differences regarding bond longevity to enamel. Scotchbond Universal and Adper Single Bond might present more water/alcohol than the others that would explain lower bond strength values [3].

Vermelho et al. [18] did not find bond strength reduction for this Universal adhesive until one year, but its means were lower than the control that used the hydrophobic bonding resin of a three-steps etch-and-rinse adhesive. Studies have shown that the effective adhesion of composite resins to enamel occurs when the enamel is previously etched with 30 to $40 \%$ phosphoric acid for 15 to 60s before application of a hydrophobic resin monomer [21-23].

For dentin bond strength, although differences were observed among adhesives at one week, no significance difference was noted among them at eighteen months, with varied percentage of bond strength reductions. Prime\&Bond Active showed the highest initial bond strength and the highest percentage of reduction, while other adhesives presented similar percentage of reduction. This Universal adhesive contains two functional monomers (10-MDP and PENTA) that provide high bond strength, but its hydrophilic features impair the adhesion after long-term storage, causing the greatest reduction in bond strength.

The etch-and-rinse yielded the lowest dentin bond strength for Adper Single Bond Plus at one week, demonstrating that self-etching mode of Universal adhesives worked better, but at eighteen months they did not differ from the control adhesive. This two-steps etch-and-rinse is alcoholic solution with $\mathrm{pH}=4.7$ and presents hydrophilic features, since it contains HEMA and copolymers of organic acids. The high hydrophilicity of adhesives does not create bonded interfaces of long-term durability [24].

The omission of acid etching for applying Universal adhesives is possible, because they contain functional monomers that ensure the adhesiveness to hard dental tissues. Prime\&Bond Active adhesive contains two phosphate monomers (10-MDP and PENTA), different cross-linking agents for polymeric formation and isopropyl alcohol as an organic solvent, with a $\mathrm{pH}$ of 2.5. A study showed stable dentin bond strength of Prime\&Bond Active adhesive until one year [25], but this study reported reduction after eighteen months.

Ambar Universal and Scotchbond Universal adhesives also contain the 10-MDP as functional monomer in an alcoholic solution of $\mathrm{pH}$ around 2.7. Studies have demonstrated that adhesives containing 10-MDP monomer present consistent bonding performance, particularly with regard to long-term durability [17,25-27]. However, the overall composition of adhesive also influence on the results, even containing 10-MDP monomer. This functional monomer interacts chemically with hydroxyapatite and forms a hydrolytically stable bond with calcium [28]. However, both adhesives present di- and methacrylates with hydrophilic features, which explain the enamel and dentin bond strength reductions after eighteen months of water-storage. Other studies have also demonstrated bond strength decreases for these adhesives after long-term storage $[18,29,30]$.

For enamel and dentin, adhesive failure (Figure 1) between the tooth and bonding agent (type 1) presented high incidence mainly for Universal adhesives (Tables IV to VII). Because both hard dental tissues were not etched, the bonding agent did not penetrate deeply into enamel and dentin. Thus, the bonding mechanism of self-etching adhesives occurs more superficially that results in high prevalence of adhesive failures. Mixed failures (type 5) were also observed frequently (Figure 2), regardless the type of adhesive (Universal adhesives or Adper Single Bond Plus). This failure mode is a non-uniform fracture, involving all structures of composite-adhesive-tooth interface. The strong interaction among interface structures (composite, adhesive and tooth/enamel or dentin) tends to yield this type of failure type 5 [31].

In this study, the bond strength of universal adhesive systems was performed to enamel and dentin substrates, comparing a conventional etch \& rinse adhesive with three Universal adhesives after 7 days and 18 months of water storage. Because Universal adhesives presented similar results compared to the conventional adhesive, they can be considered alternative bonding agents for clinical use, since they are applied to unetched surfaces, saving acid etching, rinse and moisture control steps. Besides the simplification, Universal adhesives are indicated to be applied to indirect restorative materials for cementation [2,32], 
which were not recommendations of previous generations of adhesive systems.

\section{CONCLUSION}

The adhesives applied to enamel and dentin presented differences among them depending on the evaluation time. Water-storage for eighteen months reduced the enamel and dentin bond strengths of control and all universal adhesives.

\section{Acknowledgments}

To undergraduate students that helped to develop the study.

\section{Conflict of Interest}

No conflicts of interest declared concerning the publication of this article.

\section{Funding}

This study was financed in part by University of the Joinville Region (Project UNIFOP), University of Vale do Itajai (Scientific Initiation Studies and using of laboratories) and Coordenação de Aperfeiçoamento de Pessoal de Nível Superior Brasil (CAPES) - Finance Code 001 and the National Counsel of Technological and Scientific Development (CNPq - process \# 304692/2018-2), Brazil.

\section{Regulatory Statement}

Non.

\section{REFERENCES}

1. Van Meerbeek B, Yoshihara K, Yoshida Y, Mine A, De Munck J, Van Landuyt KL. State of the art of self-etch adhesives. Dent Mater. 2011;27(1):17-28. http://dx.doi.org/10.1016/j.dental.2010.10.023. PMid:21109301

2. Rosa WL, Piva E, Silva AF. Bond strength of universal adhesives: $A$ systematic review and meta-analysis. J Dent. 2015:43(7):765-76. http://dx.doi.org/10.1016/j.jdent.2015.04.003. PMid:25882585.

3. Takeda M, Takamizawa T, Imai A, Suzuki T, Tsujimoto A, Barkmeier WW, et al. Immediate Enamel bond strength of universal adhesives to unground and ground surfaces in different etching modes. Eur J Oral Sci. 2019;127(4):351-60. http://dx.doi. org/10.1111/eos.12626. PMid:31206905.

4. da Cunha SR, Ramos PA, Haddad CM, da Silva JL, Fregnani ER, Aranha AC. Effects of different radiation doses on the bond strengths of two different adhesive systems to enamel and dentin. J Adhes Dent. 2016;18(2):151-6. PMid:27022644.

5. Takamizawa T, Barkmeier WW, Tsujimoto A, Suzuki T, Scheidel $\mathrm{DD}$, Erickson RL, et al. Influence of different pre-etching times on fatigue strength of self-etch adhesives to dentin. Eur J Oral
Sci. 2016;124(2):210-8. http://dx.doi.org/10.1111/eos.12253. PMid:26918658.

6. Buonocore MG. A simple method of increasing the adhesion of acrylic filling materials to enamel surfaces. J Dent Res. 1955;34(6):849-53. http://dx.doi.org/10.1177/002203455503 40060801. PMid:13271655.

7. Yoshihara K, Hayakawa S, Nagaoka N, Okihara T, Yoshida Y, Van Meerbeek B. Etching efficacy of self-etching functional monomers. J Dent Res. 2018;97(9):1010-6. http://dx.doi. org/10.1177/0022034518763606. PMid:29554434.

8. Garcia RN, de Goes MF, Giannini M. Effect of water storage on bond strength of self-etching adhesives to dentin. J Contemp Dent Pract. 2007;8(7):46-53. http://dx.doi.org/10.5005/jcdp8-7-46. PMid:17994154.

9. Cuevas-Suárez CE, da Rosa WLO, Lund RG, da Silva AF, Piva E. Bonding Performance of universal adhesives: an updated systematic review and meta-analysis. J Adhes Dent. 2019;21(1):726. PMid:30799468.

10. Papadogiannis D, Dimitriadi M, Zafiropoulou M, Gaintantzopoulou MD, Eliades G. Universal adhesives: setting characteristics and reactivity with dentin. Materials (Basel). 2019;27;12(10):1720.

11. Forgerini TV, Ribeiro JF, Rocha RO, Soares FZ, Lenzi TL. Role of etching mode on bonding longevity of a universal adhesive to eroded dentin. J Adhes Dent. 2017;19(1):69-75. PMid:28195274.

12. Van Landuyt KL, De Munck J, Mine A, Cardoso MV, Peumans M, Van Meerbeek B. Filler debonding \& subhybrid-layer failures in self-etch adhesives. J Dent Res. 2010;89(10):1045-50. http:// dx.doi.org/10.1177/0022034510375285. PMid:20631093.

13. Giannini M, Makishi P, Ayres AP, Vermelho PM, Fronza BM, Nikaido T, et al. Self-etch adhesive systems: a literature review. Braz Dent J. 2015;26(1):3-10. http://dx.doi.org/10.1590/01036440201302442. PMid:25672377.

14. Kawazu M, Takamizawa T, Hirokane E, Tsujimoto A, Tamura T, Barkmeier WW, et al. Comparison of dentin bond durability of a universal adhesive and two etch-and-rinse adhesive systems. Clin Oral Investig. 2020;24(8):2889-97. http://dx.doi. org/10.1007/s00784-019-03153-y. PMid:31754869.

15. Valizadeh S, Moradi A, Mirazei M, Amiri H, Kharazifard MJ Microshear bond strength of different adhesive systems to dentin. Front Dent. 2019;16(4):265-71. PMid:32342055.

16. Muñoz MA, Luque-Martinez I, Malaquias P, Hass V, Reis $A$, Campanha $\mathrm{NH}$, et al. In vitro longevity of bonding properties of universal adhesives to dentin. Oper Dent. 2015;40(3):282-92. http://dx.doi.org/10.2341/14-055-L. PMid:25405904.

17. Makishi P, André CB, Ayres APA, Martins AL, Giannini M. Effect of storage time on bond strength and nanoleakage expression of universal adhesives bonded to dentin and etched enamel. Oper Dent. 2016;41(3):305-17. http://dx.doi.org/10.2341/15163-L. PMid:26666389

18. Vermelho PM, Reis AF, Ambrosano GM, Giannini M. Adhesion of multimode adhesives to enamel and dentin after one year of water storage. Clin Oral Investig. 2017;21(5):1707-15. http:// dx.doi.org/10.1007/s00784-016-1966-1. PMid:27714528.

19. Shimada Y, Yamaguchi S, Tagami J. Micro-shear bond strength of dual-cured resin cement to glass ceramics. Dent Mater. 2002;18(5):380-8. http://dx.doi.org/10.1016/S01095641(01)00054-9. PMid:12175577.

20. Short GM, Hembree JH Jr, McKnight JP. The bond strengths of resin systems to etched enamel. J Prosthet Dent. 1976;36(5):53843. http://dx.doi.org/10.1016/0022-3913(76)90303-6. PMid:789872.

21. Guba CJ, Cochran MA, Swartz ML. The effects of varied etching time and etching solution viscosity on bond strength and enamel morphology. Oper Dent. 1994;19(4):146-53. PMid:9028234. 
22. Fanchi M, Breschi L. Effects of acid-etching solutions on human enamel and dentin. Quintessence Int. 1995;26(6):431-5. PMid:8602425.

23. Lopes GC, Thys DG, Klaus P, Oliveira GM, Widmer N. Enamel acid etching: a review. Compend Contin Educ Dent. 2007;28(1):18-24, quiz 25, 42. PMid:17278628.

24. Tay FR, Pashley DH. Have dentin adhesives become too hydrophilic? J Can Dent Assoc. 2003;69(11):726-31. PMid:14653938.

25. Fabião AM, Fronza BM, André CB, Cavalli V, Giannini M. Microtensile dentin bond strength and interface morphology of different self-etching adhesives and universal adhesives applied in self-etching mode. J Adhes Sci Technol. 2021:35(7):723-32. http://dx.doi.org/10.1080/01694243.2020.1817722.

26. Peumans M, Kanumilli P, De Munck J, Van Landuyt K, Lambrechts $P$, Van Meerbeek B. Clinical effectiveness of contemporary adhesives: a systematic review of current clinical trials. Dent Mater. 2005;21(9):864-81. http://dx.doi.org/10.1016/j. dental.2005.02.003. PMid:16009415

27. Kakiuchi Y, Takagaki T, Ikeda M, Sato T, Matsui N, Nikaido T, et al. Evaluation of MDP and NaF in two-step self-etch adhesives on enamel microshear bond strength and morphology of the adhesive-enamel interface. J Adhes Dent. 2018;20(6):527-34. PMid:30564799.
28. Yoshida Y, Nagakane K, Fukuda R, Nakayama Y, Okazaki M, Shintani $H$, et al. Comparative study on adhesive performance of functional monomers. J Dent Res. 2004:83(6):454-8. http:// dx.doi.org/10.1177/154405910408300604. PMid:15153451.

29. Cardoso MV, de Almeida Neves A, Mine A, Coutinho E, Van Landuyt K, De Munck J, et al. Current aspects on bonding effectiveness and stability in adhesive dentistry. Aust Dent J. 2011;56(Suppl 1):31-44. http://dx.doi.org/10.1111/j.18347819.2011.01294.x. PMid:21564114.

30. Cardoso GC, Nakanishi L, Isolan CP, Jardim PD, Moraes RR. Bond stability of universal adhesives applied to dentin using etch-and-rinse or self-etch strategies. Braz Dent J. 2019;30(5):467-75. http://dx.doi.org/10.1590/01036440201902578. PMid:31596331.

31. Pashley DH, Sano H, Ciucchi B, Yoshiyama M, Carvalho RM. Adhesion testing of dentin bonding agents: a review. Dent Mater. 1995;11(2):117-25. http://dx.doi.org/10.1016/01095641(95)80046-8. PMid:8621032

32. Makishi P, André CB, Silva JL, Bacelar-Sá R, Correr-Sobrinho L, Giannini M. Effect of storage time on bond strength performance of multimode adhesives to indirect resin composite and lithium disilicate glass ceramic. Oper Dent. 2016;41(5):541-51. http:// dx.doi.org/10.2341/15-187-L. PMid:27379836.

Rubens Nazareno Garcia

(Corresponding address)

Universidade do Vale do Itajaí, Curso de Odontologia, Área Materiais Dentários e

Clínica Integrada, Itajaí, SC, Brasil..

E-mail: rubensgarcia@univali.br

Date submitted: 2021 Feb 11

Accepted submission: 2021 June 01 